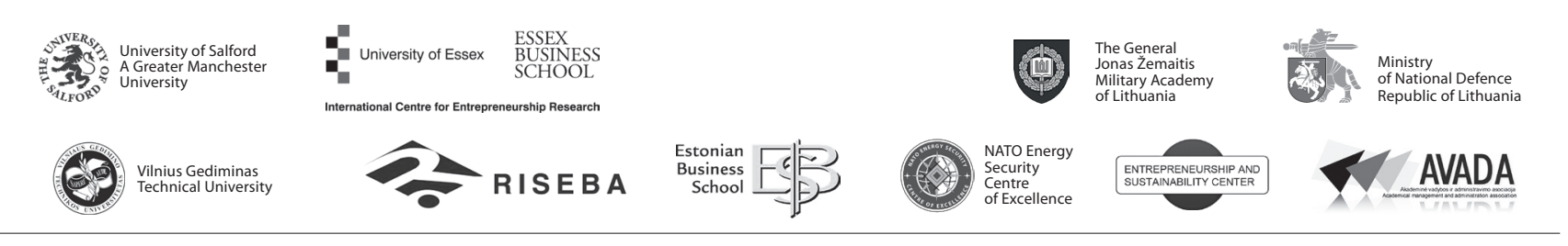

\author{
JOURNAL OF SECURITY AND SUSTAINABILITY ISSUES \\ ISSN 2029-7017 print/ISSN 2029-7025 online \\ 2017 September Volume 7 Number 1 \\ http://dx.doi.org/10.9770/jssi.2017.7.1(3)
}

\title{
DECISION MAKING OF THE ENSURING PUBLIC SECURITY AT THE LEVEL OF THE STATE TERRITORIAL BORDERS
}

\author{
Vladas Tumalavičius ${ }^{1}$, Saulius Greičius ${ }^{2}$ \\ ${ }^{1}$ The General Jonas Žemaitis Military Academy of Lithuania, Šilo Str. 5A, Vilnius LT-10322, Lithuania \\ ${ }^{2}$ Mykolas Romeris University, Faculty of Public Security, V. Putvinskis Str. 70, Kaunas LT-44211, Lithuania \\ E-mails: ${ }^{1}$ vladas.tumalavicius@gmail.com; ${ }^{2}$ s.greicius@mruni.eu
}

Received 15 February 2017; accepted 20 May 2017

\begin{abstract}
The article presents the current issues and latest trends of the legal and administrative aspects of ensuring public security in the field of state border protection. Firstly, the research reveals aspects of the public security threats in the sphere of national border security. Secondly, discusses the administrative legal regimes of the state border and frontier. Further discussion pertains to the functions and strategic goals of the State Border Guard Service, and the activity-related problems are elaborated. Finally, attention is devoted to one of the significant priorities, aiming at ensuring public security in this field - the EU external border control and protection. The authors applied general scientific methods of studying objective reality, peculiar to legal sciences: systematic document analysis, meta-analysis, structural-functional analysis, teleological, comparative, critical approach, generalisation and prediction. As a result in this research is emphasised the importance of decentralisation in ensuring public security at the level of the state territorial borders; the main guidelines of modernisation in this field are presented.
\end{abstract}

Keywords: public security, state territorial border, EU external border, protection, optimization, modernization.

Reference to this paper should be made as follows: Tumalavičius, V.; Greičius, S. 2017. Decision Making of the Ensuring Public Security at the Level of the State Territorial Borders, Journal of Security and Sustainability Issues, 7(1): 27-37.

DOI: http://dx.doi.org/10.9770/jssi.2017.7.1(3)

JEL Classifications: K1, K14, F52

\section{Introduction}

There are various threats which affect security of sustainable regional development (Grubicka, Matuska 2015; Limba et al. 2017; Prause 2016; Beifert 2016; Štitilis et al. 2016; Lankauskienė, Tvaronavičienė 2012; TeivānsTreinovskis, Jefimovs 2012; Tumalavičius et al. 2016; Tumalavičius 2016; Tvaronavičienė 2016; Zahars, Stivrenieks 2015).

One specific kind of threats might be determined by location of country. The geopolitical position of Lithuania determines the state border be assigned strong guarding. The various issues pertaining to public security, organization and coordination of the state border protection were explored by S. Greičius (2005), D. Seniutienè (2005, 2011, 2013), G. Ivoška (2011) and A. Kuksaite (2005, 2007), who underlined also and the priority problem of safeguarding the European Union internal borders.

Within the first half of 2015, 96 cases of violation of the state border of the Republic of Lithuania were fixed, 151 border violators were detained, of which 16 were returned by the neighboring states. Comparing the data 
of the recent years, it may be stated that the number of state border violations at the EU external border went on decreasing.

For example, the fixed violations at the border with the Republic of Belarus were by 21.3 percent lower than in 2014, and at the border with the Russian Federation the number of violations has been also declining $(-21$ percent). Nevertheless, the decreased number of the fixed state border violations by 28.9 percent and the practically unchanged number of detained state border violators disclose "the intensification of illegal state border violations in terms of quantity - groups of more numerous illegal migrants are detained." It should also be noted that the decline in the number of violations was mostly conditioned due to the strengthening of border guarding with the efforts of both the State Border Guard Service at the Ministry of the Interior (further the SBGS) and other institutions, especially when setting up surveillance systems (Thematic Overview 2015).

As stated in the Public Security Development Program for 2015-2025 (The Seimas of the Republic of Lithuania 2015), one of the main risk factors of public security at the state border remains illegal migration. After Lithuania has become a full-fledged member of the states within the Schengen area, the number of aliens, detained in the state territory as illegally staying or attempting to cross it, increased. Many illegal migrants still treat Lithuania as a transit country on their way to Western Europe or the Scandinavian countries. Large numbers of illegal migrants come to Lithuania from the Republic of Belarus; therefore, a significant step should be taken to make a return (readmission) agreement in the name of Lithuania or the EU with the Republic of Belarus.

Citizens from the Member States may travel in the Schengen area unrestricted without visas and cross-border check procedures irrespective of their travel purpose (Nedzinskas 2007). This may become an important challenge for national and regional security, since the mobility and transnational character of organized criminal groups are augmenting. A still more serious problem is becoming the immigrants from third countries. As a result of the conflict in Syria, Europe has confronted with the unprecedented crisis of refugees (Kahdo, Amireh 2015). Even though the South European states had to meet biggest challenges in the face of this crisis, this demographic crisis, no doubt, will have an impact on other European regions, including the Baltic States. Growing multiculturalism makes one to search for qualitatively new security solutions, which may be defined as a phenomenon of ethnocultural fragmentation of the society, directed against culture as a manifestation of the identity of a nation and based on a liberal conception of cultural diversity (Amilevičius, Andrejevas 2012).

One of the consequences of multiculturalism is the effect of "sandwich civilization", describing a postnational state which is "the confederation of completely autonomous communities. All taken together, they form one element, whereas inside that element they do not merge together, do not penetrate into one another. (...) The state just tackles general and technical issues“ (Amilevičius, Andrejevas 2012). Undoubtedly, the qualitative protection of the state border will not have an effect on these processes, but can greatly reduce their negative aftermaths, for instance, when controlling the illegal migration flows and strengthening the EU external border protection.

Two thirds of the State border transgressions are linked with smuggling (Thematic Overview 2015). The illegally imported goods diminish the profits of persons, legally operating and paying taxes; no taxes are paid for such goods; therefore, part of income is lost for the state budget and the principles of fair competition are distorted. The income raised from the illegal international trade is also used for financing of other criminal acts. As claimed in the Public Security Development Program, at present barely in nine Lithuania's border control points, X-ray control systems are used for checking trucks and transported cargo and containers. Their use should be expanded to raise the effectiveness of customs clearance procedures The Seimas of the Republic of Lithuania 2015). The main reasons for smuggling are non-equivalence of prices, incompatibility of the labor market, inefficient control of customs transit procedures, insufficient financial activity control of trade enterprises and other economic entities, imperfect development and education of public spirit (Baltrūnienè, Šarauskas 2011). Despite of the complexity of a smuggling problem, the identification and implementation of the adequate state border protection measures have a big effect on problem solving. 
Discussing the problems of ensuring public security in the field of the state border protection, it is expedient to focus on the main trends in the administrative legal regimes of the state border and frontier, the peculiarities of the activities of the key institution responsible for the state border protection - the State Border Guard Service at the Ministry of the Interior - as well as the implementation of the main state border guard priority - EU external border protection.

\section{Improvement of the state border and frontier administration system}

In the Law on the Basics of National Security, a reliable control and guarding of the state border meeting the requirements set by the European Union with a particular attention devoted to the control and guarding of the EU external border is indicated as one of the priorities of a public security policy. The state border and frontier legal regimes shall be laid down and the organization of the state border guarding shall be regulated by law.

The administrative legal regime of the state border guarding consists of constitutional and legal norms, identifying the legal grounds of the administrative legal regime thereof. The state border guarding is also based on international legal norms, general principles of international law, and internal legal norms of the state, regulating the activities of the state border guarding subjects. The administrative legal regime of the state border guarding is comprised of the totality of legal measures, ensuring the implementation of legal norms in the field of the state border protection, and of the legal mechanism of material supply which is intended for the functioning of the administrative legal regime of the state border guarding.

The state border guarding legal regime ensures that persons would adhere to the state border and frontier legal regimes and to the operation regulations of the border control points. The state border guarding administrative legal regime may be subdivided into the legal regimes of the state border, frontier, and border control points.

The Constitution of the Republic of Lithuania (1992) does not contain any article, intended for the state border guarding, except for general norms regulating territorial integrity and indivisibility of the state. The core legal acts regulating the provisions of the state border protection is the Law on the State Border and Protection thereof (2000). This law is targeted to establish the legal regimes of the state border and frontier, and to regulate the activity of border control points and organization of the guarding of the state border. Part 2 of Article 1 of the Law enforces the provision that the state border of the Republic of Lithuania shall be inviolable. This provision fills a certain gap in the Constitution, being a grundnorm in the state border protection system. Article 2 of the Law defines the state border as the line and the vertical surface extending along this line, delineating the limits of the territory of the Republic of Lithuania on land, in the entrails of the earth, in air space, inland waters and the territorial sea, and the depths thereof.

Protection of the state border is described as the measures stipulated by legal acts being designed to avoid unlawful changes in the state border demarcation; to ensure that natural and legal persons would adhere to the state border legal regime, to the frontier legal regime, and to the rules of operating border control points; to enforce other vitally important interests of the persons, the society, the state at the border control points, and in places where the border legal regime is in force. The state border legal regime is defined as the procedure established by legal acts for determining, marking, crossing, and administrating the state border.

The legal regime of the frontier means enforcement of the guarding of the state border in the frontier zone and in the territorial sea by means of laws and other legal acts, establishing the rules for the stay of persons, as well as the procedure of implementing their other rights and behavior rules. The Law also regulates the main legal regimes of the frontier and of the operation of border control points, emphasizing that the State Border Guard Service shall perform the control of the frontier regime (Article 17), and the control of the legal regime of the activities of border control points shall be implemented by the State Border Guard Service, customs office and other inspecting institutions within their powers.

Making analysis of the provisions of the Law on the State Border and the Protection Thereof, attention should 
be drawn to the fact that they are comparatively not exhaustive, here only the main concepts are characterized and the competences of institutions responsible for the state border protection are described. It is to be emphasized that the law under discussion has already been adopted in 2000, when the Republic of Lithuania was neither a member of the NATO nor the EU.

Evidently, during the law adoption the topicalities and problems related to the state border protection have been completely different. Certainly, the law was amended more than once, revised and adjusted to the international and EU legal acts, inter alia the Schengen Convention. However, frequent amendments and corrections of the law predetermined its fragmentary character and have not solved its non-compliance with the geopolitical tendencies of the period. In fact, quite a number of urgent provisions pertaining to the state border protection are regulated in the Law on the State Border Guard Service (2000), describing therein more broadly the powers of this institution. Nevertheless, the choice of such legal regulation is again subject to discussion - both legal acts are comparatively small in scope, therefore, a logical conclusion comes forth naturally that they are to be joined into one - the Law on the State Border and the Protection Thereof - which would contain all the principal provisions regulating the state border and frontier administrative legal regimes, necessarily envisaging additionally the contemporary tendencies, complying with the priority trends in the state border protection (especially the EU external border protection) and objectives.

It is also notable that another statutory implementing legal act of a substantially big scope and topical for administrative legal regimes of the state border protection is the Border Control Regulations approved by order of the Commander of the State Border Guard Service (2012). The purpose of the Border Control Regulations is to regulate planning, organizing, and executing the state border surveillance and cross-border checks by the State Border Guard Service and its structural units being involved in organizing and implementing the Service functions in the assigned frontier section, part of the territorial sea, marine, airport or some other established territory. Item 6 of the Regulations defines the border control planning as "the purposeful activity for organizing the border surveillance and cross-border checks, pursuing other goals and tasks set for border control or ensuring other functions of the Service."

It is also laid out that border control planning and organizing within the frontier station operation territory consist of the drafting of the unit commander's order on border control, evaluation of the situation at the frontier station operation territory, monthly shift scheduling, drafting of border guard shift working plan and completing of shift official worksheets. Further, all these stages are regulated in detail in the Border Control Regulations as well as the types of border guards, separate organizational aspects of their service (e.g., laying an ambush, competences of a video and/or signal system operator, etc.). In making an analysis of this legal act, a focus on the technical aspects of the activities of the border control officers is striking the eye most of all, although the principles of their activities, rights and duties have not been regulated more comprehensively.

It is noteworthy that these aspects are not regulated by either the Law on the State Border Guard Service or the Law on the State Border and Protection Thereof (the latter only succinctly mentions the core principles of the State Border Guard Service activities). Therefore, if a proposal to reform the legal regulation of this area is implemented by regulating all cornerstone provisions in a single modernized Law on the State Border and Protection Thereof and by drafting the project thereof, the above-mentioned aspects must be included in the provisions of the future law.

In summary it should be said that administrative legal regimes of the state border guard, frontier and border control points are topical for the state border protection. The necessity to modernize the present legal regulation is witnessed by the fact that currently the state border protection provisions are regulated by the two key laws: Law on the State Border and Protection thereof and Law on the State Border Guard Service, which should be logically and expediently incorporated into one.

It should be also taken into account that the above laws have already been adopted in 2000, when the Republic of Lithuania was neither a member of the NATO nor the EU; the laws have been amended more than once, 
corrected and adjusted to international and EU legislation, inter alia the Schengen Convention, this predetermining their fragmentary character and not tackling their non-compliance with the geopolitical tendencies of the period.

Therefore, it would be expedient to adopt the qualitatively new Law on the State Border and Protection Thereof, containing therein all the principal provisions regulating the state border and frontier administrative legal regimes, additionally necessarily foreseeing the state border guard priority trends in compliance with contemporary tendencies (especially the EU external border protection) and objectives.

\section{Trends in the activity improvement of the state border guard service}

The Law on the Basics of National Security states that the purpose of the State Border Guard Service is to implement the protection of the state border on land, in the sea, in the Curonian Lagoon and in frontier inland waters and the state cross-border control, to prevent and regulate the frontier incidents. The status, structure, functions, organizational basis, funding, the rights and duties of the officers of the State Border Guard Service (SBGS) are identified by the Law on the State Border Guard Service (2000). Pursuant to Article 2, SBGS is charged with the implementation of the policy of state border guarding and cross-border control, and in wartime to defend the state as an integral part of the armed forces. Meanwhile, the Ministry of the Interior guides the implementation of the policy of state border guarding and controls it. It is also regulated that SBGS activities are based on the principles of lawfulness, respect to human rights and freedoms, adjustment of the officer's personal freedom and statutory discipline, constant readiness, publicity and confidentiality adjustment, though the content of these principles has not been elaborated. In the same article it is regulated that SBGS shall conduct criminal intelligence, control of the state migration processes, and shall be entitled to initiate and control pre-trial investigations.

Article 5 regulates that SBGS functions are:

- to guard the state border;

- to exert control over persons and vehicles crossing the state border;

- to enforce the legal regime of the frontier and, within the scope of its competence, the regime of border control points;

- to take part in implementing control over the state migration processes;

- to take part in ensuring public order in the frontier zone;

- to defend the state in time of war as an integral part of the armed forces;

- to take part in the activities of international organizations;

- to maintain constant readiness in renewing the frontier check at the internal border.

It is also indicated that this list of functions is not final; moreover, the SBGS implements the functions referred to in this article while operating publicly and, if necessary, conducts criminal intelligence operations. Further the law details the powers of the Service by the functions regulated in the article. It is not clear, however, why only some functions are distinguished in this case.

Probably, it is also partly understandable that there is no necessity to elaborate how the SBGS gets involved in the military defence in time of war, even though it is completely not clear why other functions are not given in detail, for example, how the SBGS takes part in implementing control over migration processes. The legislator in Article 5 has enforced a list of functions which is not final.

This presupposes a premise that the core and most important SBGS functions have been distinguished. Nevertheless, the further elaboration of such functions at random is not clear and hardly justified. Also, three articles are incorporated into the law not very consistently: Article $7^{1}$ regulating therein the right of SBGS to receive information, Article $7^{2}$ regulating SBGS data management, and Article $7^{3}$ regulating the right of persons to obtain information. However, the inclusion of such provisions among SBGS functions makes such regulation inconsistent. 
It is also noteworthy that no consistent regulation of the rights and duties of the officers exists, even though the powers of officers in various fields are especially widely regulated and their responsibility is outlined, whereas the main rights of a SBGS officer have not been enforced. Upon making notices as regards some provisions and their non-systematic character, a general criticism of this legal act is also to be rendered.

Firstly, it should be said that as previously mentioned a conclusion may be drawn that the Law on the State Border Guard Service should be an integral part of the Law on the State Border and Protection Thereof. Secondly, the former does not foresee the SBGS priority objectives and tasks. In fact, these issues are discussed in the SBGS Regulations (Republic of Lithuania Government Resolution No. 194, 2001), wherein the norms of the Law on the State Border Guard Service are actually repeated, whereas the SBGS Regulations are just the statutory implementing legal act with the lower force of law. In addition, both the Law on the State Border Security Service and the SBGS Regulations have been adopted prior to Lithuania's accession to the EU. After Lithuania joined the EU and Schengen area, the provisions of these legal acts have been changed more than once, though it was neither systematic nor consistent; therefore, the SBGS strategic goals have not been emphasized.

It should be underlined that neither the Law on the State Border Guard Service nor the Law on the State Border and Protection Thereof as well as the Regulations have enforced the priority goal of the EU external border protection; not any account is taken of contemporary geopolitical tendencies.

This presupposes the necessity to alter the legal regulation of the SBGS activity by regulating the SBGS activity in the Law on the State Border and Protection Thereof rather than in a separate Law on the State Border Guard Service; foreseeing the SBGS strategic goals and tasks (inter alia the priority of the EU external border protection) in the Law, to adjust the norms of the Law and the SBGS Regulations seeking to achieve that the Regulations would not mechanically reiterate the norms of the Law, but would regulate those issues on the SBGS activities that are not expedient to be regulated at a level of the law. Mention should be also made of certain practical problems relevant to the SBGS activities.

Primarily, it should be noted that the problem of human resources and the adequate qualification of the staff is of importance to many institutions.

On the one hand, upon Lithuania's joining the Schengen area, the control of the border with Poland and Latvia has declined.

On the other hand, Lithuania has become the border state in the Schengen area and that is why the external border control should be strengthened. For example, according to J. Baltrūnienè and G. Šarauskas (2011), "After Lithuania has become the EU member, smuggling as a social phenomenon has not disappeared and its scale from the start of the border liberalization (...) has increased considerably." Therefore, as V. Andrejevas (2012) claims, "Lithuania's membership in the European Union requires that the external wall protection and crossborder checks be conducted by the staff with special training." However, the profession of a border guard for most of future students does not seem perspective; moreover, part of the trained professionals get employed in other structures. Therefore, currently, higher attention is attempted to be focused on the employment of graduates in the SGBS and for quality enhancement of studies. Competence of the already working SBGS officers is also striven to be raised (Andrejevas 2012).

In summary, one concludes that the necessity exists to change the legal regulation of the SBGS activities by regulating the SBGS activities in the Law on the State Border and Protection Thereof rather than in a separate Law on the State Border Guard Service, envisaging the SBGS strategic targets and tasks (inter alia the priority of the EU external border protection) in the Law; to adjust the norms of the Law and the SBGS Regulations, seeking to achieve that the Regulations would not mechanically reiterate the norms of the Law but would regulate those issues of the SBGS activities that are not expedient to be regulated at the legal level. 


\section{Tendencies in the improvement of the European Union external border protection}

Free movement of persons and goods in the EU space, safe and swift movement of persons and goods through the EU external borders is one of the cornerstones of the EU socio-economic model to be related "with the constant need to improve the regulatory environment and institutional basis" (Effective Protection of EU...2012). According to S. Greičius and D. Seniutienè (2005), "refusal of cross-border checks at the internal borders inevitably means both the national and public security deficit, since the Member States are losing an important national tool enabling to control the persons crossing the country through the internal borders and to identify them." As underlined by A. Kuksaite (2007), "security got changed in the core when borders from external turned into internal." Therefore, a certain compensatory system is foreseen for this security deficit: certain control requirements, aims, principles, mechanisms, forms of closer cooperation of institutions responsible for the internal security have been incorporated (Greičius, Seniutienė 2005).

However, the question arises as to whether these mechanisms are implementable in Lithuania, where, as seen, the priority of the EU external border security has not been foreseen even in the basic laws regulating the state border security.

According to D. Seniutiene (2011), two categories of the borders are distinguished at the EU level: internal and external. To ensure the Schengen area security, utmost attention should be devoted to strengthening the external border security.

The objective to create the area of freedom, security and justice at the EU level has already been set in the Treaty of Amsterdam. Here the reforms on the issues of asylum, visas, immigration and external border control have been envisaged. D. Seniutiene claims that "under the protocol of the Treaty the Schengen acquis has been incorporated into the EU legislation (acquis communautaire) and has become its integral part" (Seniutienè 2011).

The Treaty of Rome has enforced unrestricted mobility and freedom of movement as one of the fundamental privileges of the EU citizens. The EU has gradually developed the large space not split by the borders of the states and giving the opportunity for the EU citizens to move without any restrictions and without cross-border control. However, the free movement of citizens from different states, differing by both cultural and social criteria, may engender the greater insecurity, especially in respect of the immigrant-receiving country (Seniutiene 2013).

An integrated border security model has been developed and used in the countries belonging to the Schengen area. This model covers certain areas (dimensions) of activities that are called four filters. These dimensions include the activities in third countries, the countries of origin and transit countries, bipartite and international cooperation, measures at the external borders and further work inside the territory (Greičius, Seniutienè 2005).

It should be noted that such integrated border security model has not been enforced in any national legal acts. The EU integrated external border protection is based on the EU internal security strategy of the Council of Europe, adopted in February of 2010. Attention in the "Internal Security Strategy for the European Union "Towards a European Security Model" Project" is focused on the EU internal security and external border protection cohesion. This concept was further elaborated in the Treaty on the Functioning of the European Union. The concept of the integrated border protection is to be perceived as "the way towards convergence of national systems in order to ensure cross-border control mechanisms for movement of persons and goods to develop the area of freedom, security and justice" (Seniutiené 2011).

Consolidation of the external borders of the Schengen area encompasses both physical and legal measures. Implementation of new technologies and surveillance facilities may be referred to as physical measures. Legal measures mean the system of responsibility for illegal border crossing, the more stringent visa issue regime. 
The Schengen information system, where data on wanted or missing persons, objects, etc. are being stored, has been implemented (Seniutienè 2010). A. Kuksaite (2005) distinguishes five essential constituent parts in the common policy relating to the integrated external border management: the common legal basis, the common activity coordination and cooperation mechanism, the common integrated risk analysis, commonly used equipment and staff training to operate it at the EU level; burden sharing among the Members States in order to join the European border security forces. The issues on the development of integrated external borders have neither been regulated in national legal acts so far, nor been accorded more considerable attention in the scholarly works. The first more distinct impetus in this field is to be related to the Public Security Development Program for 2015-2025.

One of the priority tasks under the Public Security Development Program for 2015-2025 is to ensure the effective EU external border control and to prevent illegal migration and illegal international trade (The Seimas of the Republic of Lithuania 2015). All aspects of this goal are integral and closely related; therefore, it is possible to state that the foreseen target may be implemented only by complex measures. The program also sets the key tasks to implement this goal.

The first such task is the EU external border management enhancement. This task may be implemented by getting integrated into the EU external border management system; by implementing modern border surveillance systems at the state border with the Russian Federation and the Republic of Belarus and surveillance of the sea border and by ensuring their proper functioning; by improving and modernizing the procedures of the state cross-border checks and strengthening international cooperation.

The second task covers illegal migration prevention and control strengthening. To implement this task it is necessary to enhance the interaction of institutions, responsible for migration process control, especially in the field of information exchange, and for collaboration with other EU Member States and third countries and increase their powers and capacities to react promptly, adequately and by requisite measures; to consolidate the preliminary illegal migration control by effectively using a visa issuance system; to reduce opportunities for abusing the legal ways of migration; to ensure the effective implementation of policy to return aliens to their country of origin or foreign states whereto they are entitled to go, to encourage the voluntary return, and thus to save the state funds; to more broadly disseminate information on the opportunities of legal migration of aliens, procedure of entrance into Lithuania, staying here, passing it in transit and departure. Likewise, it must be necessary to develop the effective fight against illegal trade by strengthening both national and regional coordination and interaction of competent institutions, expanding the application of prevention measures being intended for control of the turnover of illegally imported goods, etc (The Seimas of the Republic of Lithuania 2015).

As stated in the Public Security Development Program for 2015-2025, since the end of 2013 the European Border Surveillance System (EUROSUR) has started operating in the EU and is intended for the EU Member States and the European Agency for the Management of Operational Cooperation at the External Borders of the Member States of the European Union (FRONTEX) to exchange information and to mutually cooperate seeking to identify the illegal migration and transnational crime cases and to prevent them.

By the Resolution of the Government (Republic of Lithuania Government Resolution No. 444 2014) the State Border Guard Service has been appointed as the National Coordination Centre, intended to coordinate the activities, to cooperate with all the institutions, responsible for surveillance of the external borders of the EU Member States, as well as with other national coordination centers and FRONTEX, and to exchange information with these institutions within EUROSUR.

Strengthening the EU external border control, it is necessary to employ the opportunities of this system (The Seimas of the Republic of Lithuania 2015). Nevertheless, the stationary EU external border surveillance system has been implemented only in some sections of the EU external land border with the Russian Federation and the Republic of Belarus, at the approaches to some border control points and for surveillance of the territo- 
rial sea. At the end of 2014, 32 percent of the border was controlled by the stationary surveillance systems in Lithuania the EU external borders - 345 km. In the Public Security Development Program for 2015-2025, it is emphasized that state border violations reduced greatly in the state border sections where the border surveillance system is being implemented. For example, upon implementation of such systems at the border with the Russian Federation, the number of the state border violations in this border section has reduced even by 78 percent in 2010-2013.

Therefore, the program focuses on the aim to constantly strengthen the available forces, to implement the modern border surveillance systems at the EU external border, to improve their use with account of the changes in the external and internal risk factors and threats, and to ensure the efficient functionality of the implemented border surveillance systems. In the state border sections where the stationary border surveillance systems have been installed the constant patrolling should be replaced by the operational reaction to the illegal state border crossings and efficient prevention of those crossings (The Seimas of the Republic of Lithuania 2015).

Currently, an opportunity exists at the border control points to conduct checks of electronic travel documents with electronic protection measures issued only in some states, as the system of exchange of certificates confirming the authenticity of electronic documents has not been developed. The 'smart borders' initiative envisages the broad use of biometric identifiers and electronic documents for checks at the border control points, with the assistance of the special border checking programs and creation of the common entry and departure system at the EU external border. It is necessary to improve and modernize the check procedures at the border control points and to supply SBGS officers with the most sophisticated equipment for people detection, travel document check, and vehicle inspection.

It is necessary to further strengthen cooperation with the frontier protection (coastal) services of the Baltic Sea region states, ensuring the external border surveillance in the sea, to actively participate in FRONTEX activities, other international forums and projects of the EU and Baltic Sea region states (The Seimas of the Republic of Lithuania 2015).

In summary, it should be said that refusal of cross-border checks at the internal borders after signing the Schengen Convention predetermines the deficit of public security within the state; therefore, the proper functioning of compensatory mechanisms should be ensured. The reasonable doubt arises whether these mechanisms are effectively implemented in Lithuania where, as seen, the EU external border protection priority is not foreseen even in the main laws regulating the state border protection.

The first more distinct impetus in the national lawmaking is related to the Public Security Development Program for 2015-2025 where ensuring of the efficient EU external border control and prevention of illegal migration and illegal international trade are among priority objectives. Of importance is also that SBGS is appointed as the National Coordination Centre for coordination of activities and cooperation with all institutions, responsible for the external border surveillance of the EU Member States, as well as other national coordination centers and FRONTEX, information exchange with these institutions within EUROSUR. To strengthen the EU external border control, the potentials of this system should be used effectively.

It is necessary to improve and modernize the check procedures at the border control points and to supply SBGS officers with the most sophisticated equipment for people detection, travel document check and vehicle inspection. It is necessary to further strengthen the cooperation with frontier protection (coastal) services of the Baltic Sea region states, ensuring the external border surveillance in the sea, to actively participate in FRONTEX activities, other international forums and projects of the EU and Baltic Sea region states. 


\section{Conclusions}

The necessity for modernization of the present legal regulation in the field of state border protection is witnessed by the fact that currently the state border protection provisions are regulated by the two key laws: Law on the State Border and Protection Thereof and the Law on the State Border Guard Service, which should be logically and expediently incorporated into one. The above laws have already been adopted in 2000, when the Republic of Lithuania was neither a member of the NATO nor the EU; the laws have been amended more than once, corrected and adjusted to international and EU legal acts, inter alia the Schengen Convention, this predetermining their fragmentary character and not tackling their non-compliance with the geopolitical tendencies of the period.

The reasonable doubt also arises whether these mechanisms are effectively implemented in Lithuania where, as seen, the EU external border protection priority is not foreseen even in the main laws regulating the state border protection.

\section{References}

Amilevičius, D.; Andrejevas, V. 2012. Daugiakultūriškumas saugios Europos kontekste: dabarties problematika, teoriniai modeliai ir ateities perspektyvos [Multiculturism in the Context of the Safe Europe: Current Issues, Theoretical Models and Future Development]. Public Security and Public Order, No. 8.

Andrejevas, V. 2012. Būsimų pasieniečių ịdarbinimo problemos [Employment Problems of Future Border Guards]. Public Security and Public Order, No. 7.

Baltrūnienè, J.; Šarauskas, G. 2011. Kontrabandinių nusikalstamų veikų kriminalistinè charakteristika ir praktiniai šių nusikaltimų atskleidimo aspektai Lietuvoje [The Forensic Characteristics of Contraband Criminal Acts and Practical Aspects of Crime Disclosure]. Public Security and Public Order, No. 6.

Beifert, A. 2016. Regional airports' potential as a driving force for economic and entrepreneurship development - case study from Baltic Sea region, Entrepreneurship and Sustainability Issues 3(3): 228-243. https://doi.org/10.9770/jesi.2016.3.3(2)

Greičius, S. 2005. Prievartos naudojimo ịgyvendinant Valstybès sienos apsaugos tarnybos funkcijas teisinio reguliavimo aspektai [Aspects of Legal Regulations of Employment of Compulsion in Implementing the Functions of State Border Guard Service]. Jurisprudence, $76(68)$.

Greičius, S.; Seniutienè, D. 2005. Šengeno konvencijos įtaka Lietuvos sienų apsaugos organizavimui [The Schengen Convention Influence on Lithuanian Border Organization]. Jurisprudence, 73(65).

Grubicka, J.; Matuska, E. 2015. Sustainable entrepreneurship in conditions of UN (Safety) and technological convergence, Entrepreneurship and Sustainability Issues 2(4): 188-197. Available in Internet: <https://doi.org/10.9770/jesi.2015.2.4(2)>.

Ivoška, G. 2011. Baudžiamosios politikos kontrabandos ir muitinès apgaulès kontrolès srityje igyvendinimo Lietuvos teisinėje sistemoje problemos [The Problems of Implementation of Penal Policy in the Field of Combatting Smuggling and Customs Fraud in Lithuanian Legal System]. Legal issues, 2(72).

Kahdo, K.; Amireh, F. 2015. Crisis of Refugees - Who, From Where and Why?. Available in Internet: < https://europa.eu/eyd2015/lt/ lithuanianngdo/posts/causesofrefugeeinflux>.

Kuksaitè, A. 2005. Išorinių sienų apsauga kaip vidinio Europos Sajungos saugumo garantas [External Borders Protection as Guarantee of European Union Internal Security]. Jurisprudence, 78(70).

Kuksaite, A. 2005. Išorinių sienų apsauga kaip vidinio Europos Sajungos saugumo garantas [External Borders Protection as Guarantee of European Union Internal Security]. Jurisprudence, 78(70).

Kuksaitè, A. 2007. Europos Sajungos vidinių sienų saugumą didinančios priemonès [Objects Compensating the Security of European Union Internal Borders]. Jurisprudence, 10(100).

Lankauskiené, T.; Tvaronavičienè, M. 2012. Security and sustainable development approaches and dimensions in the globalization context, Journal of Security and Sustainability Issues 1(4): 287-297. DOI: http://dx.doi.org/10.9770/jssi.2012.1.4(5)

Lietuvos Respublikos Konstitucija. [Constitution of the Republic of Lithuania]. Official gazette. 1992, No. 33-1014. 
Lietuvos Respublikos Seimo 2015 m. gegužès 7 d. nutarimas Nr. XII-1682 „Dèl Viešojo saugumo plètros 2015-2025 metų programos patvirtinimo“. [The Seimas of the Republic of Lithuania. The Public Security Development Program for 2015-2025]. TAR. 2015-05-13, No. 7293.

Lietuvos Respublikos valstybès sienos apsaugos tarnybos įstatymas. [Republic of Lithuania Law on the State Border Guard Service]. Official gazette. 2000, No. 92-2848.

Lietuvos Respublikos valstybès sienos ir jos apsaugos įstatymas. [Republic of Lithuania Law on the State Border and the Protection Thereof]. Official gazette. 2000, No. 42-1192.

Lietuvos Respublikos Vyriausybės 2001 m. vasario 22 d. nutarimas Nr. 194 „Dèl pasienio policijos departamento prie Lietuvos Respublikos vidaus reikalų ministerijos reorganizavimo ir Valstybès sienos apsaugos tarnybos prie Lietuvos Respublikos vidaus reikalų ministerijos nuostatų patvirtinimo" [Republic of Lithuania Government Resolution No. 194 of 22 March 2001 "On the Reorganisation of the Border Police Department under the Ministry of the Interior of the Republic of Lithuania and the Approval of the Regulations of the State Border Guard Service under the Ministry of the Interior of the Republic of Lithuania”]. Official gazette. 2001, No. 18-556.

Lietuvos Respublikos Vyriausybės 2014 m. gegužès 22 d. nutarimas Nr. 444 „Dèl Nacionalinio koordinavimo centro paskyrimo ir igaliojimų suteikimo“" [Republic of Lithuania Government Resolution No. 444 of 22 May 2014 "On the Appointment and Granting of Powers to the National Coordination Centre"].

Limba, T.; Plèta, T.; Agafonov, K.; Damkus, M. 2017. Cyber security management model for critical infrastructure, Entrepreneurship and Sustainability Issues 4(4): 559-573.DOI: https://doi.org/10.9770/jesi.2017.4.4(12)

Nedzinskas, E. 2007. Imigracijos įtaka visuomenès saugumui: teisiniai ir sociologiniai aspektai [The Impact of Immigration on Public Safety: Legal and Sociological Aspects]. Jurisprudence, 12(102).

Prause, G. 2016. E-Residency: a business platform for Industry 4.0?, Entrepreneurship and Sustainability Issues 3(3): 216-227. DOI: https://doi.org/10.9770/jesi.2016.3.3(1)

Seniutiené, D. 2010. Migracijos procesai po prisijungimo prie Šengeno erdvès [Migration Processes of Accession to the Schengen Area]. Public Security and Public Order, No. 4.

Seniutienè, D. 2011. Integruotas sienų saugumo modelis [The Integrated Model of Border Security]. Public Security and Public Order, No. 5 .

Seniutienè, D. 2013. Security and Mobility: The European Trends. Public Security and Public Order, No. 9.

Štitilis, D.; Pakutinskas, P.; Malinauskaitè, I. 2016. Preconditions of sustainable ecosystem: cyber security policy and strategies, Entrepreneurship and Sustainability Issues 4(2): 174-182. DOI: https://doi.org/10.9770/jesi.2016.4.2(5)

Teivāns-Treinovskis, J.; Jefimovs, N. 2012. State national security: aspect of recorded crime, Journal of Security and Sustainability Issues 2(2): 41-48. DOI: http://dx.doi.org/10.9770/jssi.2012.2.2(4)

Temine apžvalga. Situacijos prie valstybès sienos analizè. 2015 metu pusmetis [Thematic Overview. Analysis of Situation at the State Border. First Half of the Year 2015]. The State Border Guard Service at the Ministry of the Interior, 2015.

Tumalavičius, V. 2016. Security of Society in Lithuania: Concept and Scientific Fundamentals in its Ensuring. Sociālo Zinātṇu Vēstnesis. 1(22): 92-118 pp. Daugavpils Universitāte, Humanitāro un sociālo zinātṇu institūts. ISSN 1691-1881.

Tumalavičius, V.; Ivančiks, J.; Karpishchenko, O. 2016. Issues of Society Security: Public Safety under Globalisation Conditions in Lithuania, Journal of Security and Sustainability Issues 5(4): 545-570. DOI: http://dx.doi.org/10.9770/jssi.2016.5.4(9)

Tvaronavičienė, M. 2016. Start-ups across the EU: if particular tendencies could be trace, Entrepreneurship and Sustainability Issues 3(3): 290-298. DOI: http://dx.doi.org/10.9770/jesi.2016.3.3(6)

Valstybės sienos apsaugos tarnybos prie Lietuvos Respublikos vidaus reikalų ministerijos vado 2012 m. sausio 31 d. įsakymas Nr. 4-116 „Dèl sienos kontrolès nuostatu patvirtinimo“ [Order No. 4-116 "Concerning the Approval of the Border Control Regulations”]. The State Border Guard Service at the Ministry of the Interior, 2012.

Veiksminga ES išorès sienu apsauga kaip Lietuvos pirmininkavimo ES Tarybai prioritetas ES iniciatyvu ir Lietuvos interesų kontekste. Tyrimo ataskaita [Effective Protection of EU External Borders as the Priority of Lithuanian Presidency of the Council of the EU in the Context of the EU Initiatives and Lithuania‘s Interests. Study Report]. European Union, 2012.

Zahars, V.; Stivrenieks, M. 2015. Security implementation facets: peculiarities of execution of the sentence of imprisonment in respect of convicted minors, Journal of Security and Sustainability Issues 4(3): 221-231. DOI: http://dx.doi.org/10.9770/jssi.2015.4.3(3) 